\title{
PERKOTAaN Kolonial PADA ABAD XIX - XX, DI KOTA SERANG, BANTEN; KAJIAN ARKEOLOGI-HISTORIS
}

\author{
THE XIX - XX CENTURY COLONIAL URBAN IN SERANG, BANTEN; \\ AN ARCHAEO-HISTORICAL STUDY
}

\author{
Oleh Lia Nuralia \\ Balai Arkeologi Bandung \\ Jln. Raya Cinunuk Km. 17 Cileunyi Bandung 40623 \\ E-mail: liabalar@yahoo.com
}

\begin{abstract}
Abstrak
Tulisan ini bertujuan memberi gambaran tentang perkotaan kolonial di Kota Serang pada zaman Pemerintahan Hindia Belanda (Abad XIX-XX), dilihat dari perspektif arkeologis dan historis. Dengan menggunakan metode penelitian arkeologi (survei permukaan) dilengkapi dengan teknik pengumpulan data berupa wawancara (sejarah lisan), dapat diketahui bahwa pada masa kolonial Belanda telah terjadi perubahan wilayah permukiman di Kota Serang yang cukup pesat dan siginifikan, sehingga penting diungkapkan ke permukaan. Perubahan terjadi terutama dalam pembagian wilayah perkotaan dan fungsi bangunan. Secara umum wilayah permukiman di Kota Serang ketika itu terbagi ke dalam 3 bagian wilayah, yaitu: pemukiman, perkantoran, dan perdagangan. Pembagian ini sebagai hasil kajian melalui bangunan lama periode kolonial dan tinggalan budaya materi lainnya yang masih ada sekarang. Seiring dengan pembagian wilayah tersebut, juga telah terjadi perubahan bentuk dan gaya arsitektur bangunan menjadi bergaya Indis atau pencampuran antara gaya Eropa dan gaya lokal. Hal ini tampak pada bentuk bangunan tinggi, dinding tebal, bentuk atap joglo, memiliki teras atau koridor di sepanjang bangunan atau pada sebagian luar bangunan. Selain perbahan secara fisik, perubahan non fisik juga terjadi ditandai dengan adanya perubahan pola sikap atau perilaku. Masyarakat Kota Serang menjadi lebih terbuka terhadap masuknya unsur budaya asing. Juga lebih toleran terhadap perbedaan kebiasaan antar etnis yang beragam dalam masyarakat heterogen.
\end{abstract}

Kata kunci: perkotaan kolonial, pemukiman, perkantoran, perdagangan, Kota Serang, Banten. 


\section{Abstract}

The aim of this research is to describe the colonial urban in Serang, Banten during the Dutch colonial era $\left(19^{\text {th }}-20^{\text {th }}\right.$ century), based on historical remains and material culture as well. By conducting archaeological method (surface survey) and interview (oral history) it is found that there was a rapid and significant change in residence areas then, especially in zoning the urban areas and function of buildings. Generally, Serang was divided into three zones: residential, office, and commercial. Along with that zoning, there were also changes in the architecture of buildings, combining both local and European styles, called Indische style. It is seen in the form of high-rise buildings, thicker walls with joglo style for the roof, terraces or corridors along the building or outside the building. Beside physical changes, there were also nonphysical changes in term of behavioural patterns. The inhabitants of the city became more open to foreign culture and more tolerant in building relationship with other heterogeneous ethnic groups.

Keywords: colonial urban, residence, office, commercial, Serang, Banten.

\section{A. PENDAHULUAN}

Keberadaan Kota Serang tidak terlepas dari perjalanan panjang sejarah Kesultanan Banten dan Kabupaten Serang. Kesultanan Banten pada masa lalu adalah kota pelabuhan yang ramai dikunjungi para pedagang, baik dari dalam maupun luar negeri. Di antara para pedagang dari dalam negeri datang dari Cirebon, Demak, sedangkan dari luar negeri dari Cina, India, Spanyol, Portugis, Inggris, dan Belanda. Pada awalnya kedatangan bangsa Barat ketika itu bertujuan untuk memperoleh barang komoditas ekspor yang laku di pasaran dunia. Akan tetapi, semangat imperialisme dan kolonialisme bangsa Belanda khususnya memonopoli

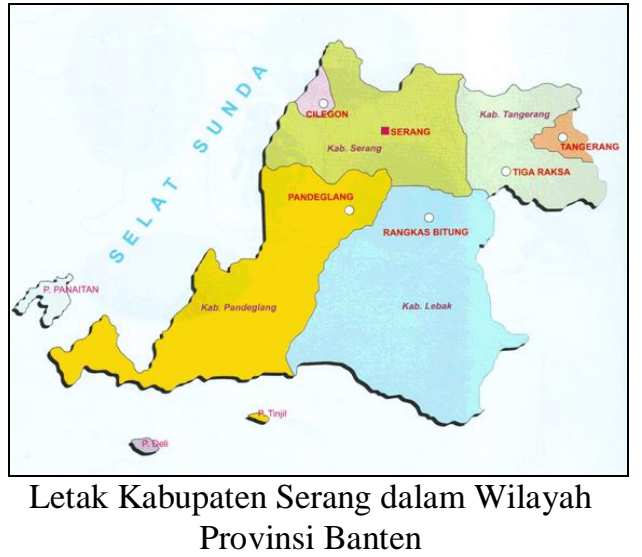

perdagangan, akhirnya menguasai seluruh sendi kehidupan masyarakat Banten. Kesultanan Banten mengalami keruntuhan. Pada perkembangan selanjutnya terbentuk Kabupaten Serang yang sekarang ini telah mengalami pemekaran menjadi kabupaten dan kota.

Kabupaten Serang sekarang memiliki luas 170.341.25 hektar, tersebar di 34 kecamatan, 353 desa, dan 20 kelurahan. Di kabupaten ini banyak ditemukan tinggalan budaya materi (material culture) dari masa prasejarah sampai masa kolonial. Di antaranya beliung persegi di Dusun Nyawana, Desa Sukamenak, Kecamatan Cikeusal. Ditemukan Situs Kubur di Kecamatan Anyer Lor dengan hasil penelitian yang dilakukan H.R. Van Heekeren dan Besuki tahun 1955, yaitu rangka manusia yang ditempatkan dengan posisi jongkok di dalam tembikar tipe tempayan. Kemudian temuan masa Hindu Buddha di Situs Banten Girang berupa bekas lokasi pemukiman/perkotaan. Selanjutnya, temuan masa Islam di Banten Lama, yaitu Komplek Keraton Surosowan, Mesjid Agung Banten, Menara Mesjid, Keraton Kaibon, dan lain-lain. Memasuki zaman kolonial Belanda, tinggalan monumental yang masih ada adalah Mercusuar Cikoneng Anyer, prasasti "titik nol" pembangunan jalan Anyer-Panarukan, 
beberapa bangunan kolonial (bangunan lama yang didirikan pada zaman kolonial Belanda) di Kota Serang, serta pemukiman kolonial/kampung kuno yang sekarang termasuk wilayah Cimuncang, Pegantungan, Kaloran, Kaujon, Kubang di Kota Serang (Tim Penyusun, 2011: 1-6).

Pengertian permukiman mempunyai lingkup tertentu, yaitu kawasan yang didominasi oleh lingkungan hunian dengan fungsi utama sebagai tempat tinggal dilengkapi dengan prasarana, sarana lingkungan, dan tempat kerja terbatas, sehingga berdaya guna dan berhasil guna, seperti: (1) jaringan jalan untuk mobilitas manusia dan angkutan barang, (2) jaringan saluran pembuangan air limbah dan tempat pembuangan sampah untuk kesehatan lingkungan, dan (3) jaringan saluran air hujan untuk drainase dan pencegahan banjir setempat. ${ }^{1}$

Berdasarkan perspektif ilmu arsitektur, pengertian permukiman (Human Settlement) merupakan tempat (ruang) untuk hidup dan berkehidupan bagi kelompok manusia. Permukiman akan selalu berkaitan dengan perumahan. Perumahan (Housing) adalah tempat (ruang) dengan fungsi dominan untuk tempat tinggal (http://kuliaharsitektur.wordpress.com/200 8/11/15/pengertian- permukiman/).

Dengan demikian, salah satu unsur permukiman adalah perumahan atau pemukiman. Istilah pemukiman menurut Mundardjito adalah wilayah tempat orang bermukim yang secara fisik dapat dilihat dengan mata. Sementara itu, istilah permukiman mengacu kepada hal-hal yang berkenaan dengan pemukiman, sehingga cakupannya lebih luas daripada pemukiman (Mundardjito, 1990: 20).

Arkeologi permukiman adalah bagian dari disiplin arkeologi yang mengkhususkan perhatiannya kepada persebaran okupasi dan kegiatan manusia, serta hubungan-hubungan di dalam satuan-

${ }^{1}$ Undang-undang Republik Indonesia Nomor 4 tahun 1992 tentang Perumahan dan Permukiman, Bab I, Pasal 1. satuan ruang. Bertujuan memahami sistem teknologi, sistem sosial dan sistem ideologi dari masyarakat masa lalu. Dalam perkembangannya untuk menganalisis pola persebaran dan hubungan terbagi menjadi tiga tingkatan, yaitu (1) mikro, memperlajari pola-pola persebaran dan hubungan dalam satu bangunan, (2) semi mikro, mempelajari pola-pola persebaran dan hubungan dalam satu situs, dan (3) makro, mempelajari pola-pola persebaran dan hubungan di dalam suatu wilayah (Mundardjito, 1990: 21-22).

Pemukiman tidak hanya tempat tinggal, tetapi ada unsur-unsur pendukung hidupnya, seperti air dan sumber makanan. Permukiman (settlement) secara formal dikaitkan dengan hal-hal yang bersangkut paut dengan cara-cara memukimkan atau proses memukimkan. Dapat pula berarti proses memukimi atau menempati tempattempat tertentu (Yunus, 1987). Secara umum mengacu kepada pengertian peninggalan yang mencerminkan aktivitas masyarakat masa lalu dalam skala dan waktu okupasi yang cukup untuk meninggalkan gambaran bentuk aktivitas tersebut (Mundardjito dalam Said dan Bambang Budi Utomo, 2006: 1)

Situs permukiman menurut Mundardjito adalah situs arkeologi berupa tinggalan-tinggalan budaya yang menunjukkan beragam aktivitas manusia. Dilihat dari fungsinya, situs arkeologi dapat berfungsi tunggal (single component) maupun ganda (multi component). Salah satunya adalah situs pemukiman. Di lokasi situs pemukiman fungsi utamanya adalah tempat bermukim atau tempat tinggal (rumah hunian), yang didukung oleh unsur-unsur penunjang kehidupan lainnya berupa pasar, tempat ibadah, makam, jalan/jembatan, dan lain-lain (Said dan Bambang Budi Utomo, 2006: 7-8).

Kota Serang ketika itu adalah salah satu kota terencana Pemerintah Hindia Belanda. Pemukiman terencana biasanya berkaitan dengan keberadaan kota. Pengertian kota menurut Max Weber mempunyai ciri-ciri, yaitu (1) adanya 
pasar, (2) memiliki sistem hukum sendiri, dan (3) bersifat kosmopolitan (Weber, 1966: 4). Kota juga merupakan suatu tempat dengan penghuninya yang dapat memenuhi sebagian besar kebutuhan ekonominya di pasar lokal. Barang-barang yang ada dihasilkan oleh penduduk setempat di pedalaman dan diperjualbelikan di pasar lokal di daerahnya (Nuralia, 2011:101).

Salah satu wilayah permukiman yang cukup besar dan ramai adalah wilayah perkotaan. Perkotaaan kolonial dalam tulisan ini mengandung pengertian wilayah kota yang sengaja dibangun oleh Pemerintah Belanda. Kota Serang sebagai kota yang sengaja dibangun oleh Pemerintah Belanda ketika itu, memiliki fasilitas-fasilitas kota yang cukup lengkap, seperti rumah tinggal, bangunan perkantoran, bangunan perdagangan (pasar), dan bangunan publik lainnya. Keberadaan beberapa bangunan tersebut telah memberi perubahan bagi Kota Serang yang cukup sifnifikan dalam perjalanan sejarah Kota Serang.

Perubahan yang terjadi memberi manfaat dan nilai guna bagi perkembangan kehidupan manusia secara umum. G.J. Reiner mengatakan bahwa tanpa pengalaman masa lalu tidak mungkin untuk membangun ide-ide tentang konsekuensi dari tindakan kita. Hal ini menunjukkan adanya hubungan masa lalu dengan masa kini untuk proyeksi di masa yang akan datang (Reiner, 1997). Menurut Martin Heidegger manusia ditandai ciri historisitas (historicity). Manusia adalah subjek sekaligus objek sejarah. Manusia terlahir dalam suatu lingkaran sejarah tertentu yang terus membentuknya, sekaligus tetap berusaha melakukan pergulatan-pergulatan dalam bentuk inovasi-inovasi kreatif untuk eksistensi dirinya dalam alur sejarah. Historisitas ini tidak saja melekat pada level individu, juga berkait dengan tatanan kebudayaan suatu masyarakat (Heidegger, 1974).

Dengan adanya perubahan fisik kota di wilayah perkotaan kolonial di Kota
Serang, juga telah berimbas kepada perubahan secara non fisik atau budaya non materi (immaterial culture). Seperti dijelaskan Kupper bahwa kebudayaan merupakan sistem gagasan yang menjadi pedoman dan pengarah bagi manusia dalam bersikap dan berperilaku, baik secara individu maupun kelompok. Kebudayaan adalah suatu kumpulan peralatan simbolik untuk mengatur perilaku, sebagai sumber informasi yang ekstrasomatik. Oleh karena itu, proses budaya haruslah dibaca, diterjemahkan, dan diinterpretasikan (Kupper; 1999: 98). Sementara itu, Clifford Geertz mengatakan bahwa kebudayaan adalah seperangkat teks-teks simbolik yang perlu diinterpretasikan maknanya sebagai suatu pola perilaku yang sifatnya konkret, suatu pendeskripsian yang sifatnya mendalam (thick description) (Geertz, 1992: 5).

Apa dan bagaimana perkotaan kolonial pada abad XIX - XX di Kota Serang, serta bagaimana nilai-nilai sejarah dan budaya yang terkandung di dalamnya, akan diuraikan dalam tulisan ini. Dengan demikian, tujuan dan manfaat tulisan ini adalah memberi gambaran tentang pembagian wilayah perkotaan di Kota Serang pada zaman Pemerintahan Hindia Belanda. Dapat memberi pengetahuan tentang nilai-nilai sejarah dan budaya, serta memberi informasi tentang kondisi sosial ekonomi masyarakat Kota Serang di masa lalu.

Tulisan ini adalah hasil penelitian dengan metode penelitian arkeologi (survei permukaan) dilengkapi teknik pengumpulan data berupa wawancara (sejarah lisan). Penelitian dilakukan tahun 2011 dengan obeservasi langsung ke lapangan, menelusuri seluruh data dan mengidentifikasi data yang diperoleh dalam kerangka waktu, bentuk, dan ruang tertentu. Kemudian ditambah hasil wawancara dengan informan yang dianggap memiliki hubungan dengan objek kajian. Dilanjutkan proses seleksi data melalui kritik sumber, proses sintesis analisis, dan penulisan secara deskriptif 
kronologis (Kuntowijoyo, 1994:21-23). Juga ditambah data baru pada saat penulisan dilakukan Februari 2012, berupa data kepustakaan dan sumber dari website internet.

\section{B. HASIL DAN BAHASAN \\ 1. Selayang Pandang Kota Serang}

Kota Serang secara geografis merupakan bagian dari wilayah Kabupaten Serang dan sebagai Ibukota Provinsi Banten. Wilayah Kota Serang terdiri dari daratan, perbukitan dan lautan dengan luas $266,74 \mathrm{~km}^{2}$, berada pada $6^{\circ} 12^{\prime}$ LS dan $106^{\circ} 15^{\prime} 02,8^{\prime}$ 'BT. Jumlah penduduk Kota Serang \pm 501,471 dengan kepadatan $1.880 / \mathrm{km}^{2}$, suku bangsa didominasi Jawa Banten, agama yang dianut mayoritas Islam, dan bahasa yang digunakan bahasa Indonesia, Sunda, dan Jawa Banten. Batas wilayah kota Serang mencakup (1) Sebelah utara dengan Teluk Banten, (2) Sebelah timur dengan Kecamatan Pontang, Ciruas, Kragilan, (3) Sebelah barat dengan Kecamatan Pabuaran, Waringin Kurung dan Kramatwaktu dan (4) Sebelah selatan dengan Kecamatan Cikeusal, Petir dan Baros. Luas wilayah Kota Serang secara administratif 26.439 ha, terdiri dari 6 kecamatan, 20 kelurahan dan 46 desa. Keenam kecamatan tersebut, yaitu (1) Serang $^{2}$, (2) Cipocok Jaya, (3) Curug, (4) Kasemen, (5) Taktakan, dan (6) Walantaka.

Wilayah Kota Serang adalah bagian dari Kabupaten Serang yang dibangun setelah Gubernur Jenderal H.W. Daendels (1808-1811) berkuasa di Hindia Belanda 1808. Pada saat itu Keraton Surosowan sebagai pusat kota Kesultanan Banten dibumihanguskan dan ditetapkan sebagai kawasan prefek/landrosambt (daerah

\footnotetext{
${ }^{2}$ Kecamatan Serang terdiri dari 12 kelurahan, yaitu (1) Serang, (2) Kaligandu, (3) Sumur Pecung, (4) Sukawana, (5) Cimuncang, (6) Terondol, (7) Unyur, (8) Kota Baru, (9) Lontar Baru, (10) Kagungan, (11) Lopang, dan (12) Cipare
}

setingkat karesidenan). Kawasan ini terbagi menjadi tiga daerah setingkat kabupaten, yaitu (1) Banten Hulu, (2) Banten Hilir, dan (3) Anyer, yang merupakan bagian dari wilayah Kabupaten Serang (Lubis, 2004: 94). Tahun 1817, Residen J. De Bruijn WD, mulai melakukan penataan kota dan pembangunan gedung pemerintahan. Selanjutnya 8 Oktober $1926^{3}$, pusat Pemerintahan Kerajaan Banten di Banten Girang dipindahkan ke wilayah Banten Lama (3 km dari Kota Serang sekarang). Pada 2 November 2007 ditetapkan sebagai kotamadya dan 17 Juli 2007 dimekarkan menjadi Kota Serang dan Kabupaten Serang. Kecamatan Serang di Kota Serang ditetapkan sebagai pusat pemerintahan kota sekaligus ibukota Provinsi Banten. Sementara itu, pusat pemerintahan kabupaten berada di Kecamatan Ciruas.

\section{Pembagian Wilayah Perkotaan di Kota Serang}

Pembagian wilayah perkotaan pada abad XIX - XX di Kota Serang dapat ditelusuri melalui tinggalan sejarah dan budaya, baik fisik maupun nonfisik. Tinggalan fisik dapat dibuktikan dengan keberadaan bangunan-bangunan lama sebagai fasilitas kota, seperti karesidenan, mesjid, rumah tinggal, gedung stasiun kereta api, pasar, dan lain-lain. Beberapa bangunan lama periode kolonial ditemukan di Kota Serang, termasuk ke dalam wilayah Kecamatan Serang. Secara umum pola tata Kota Serang terbagi ke dalam tiga bagian wilayah, yaitu: pemukiman, perkantoran, dan perdagangan.

\section{a. Pemukiman}

Pemukiman merupakan wilayah hunian atau tempat tinggal penduduk Kota Serang yang secara tata kota berada di sebelah barat aliran Sungai Cibanten. Sekarang ini lebih dikenal sebagai kampung kuno kolonial. Kampung kuno

\footnotetext{
${ }^{3}$ Tanggal 8 Oktober 1926 ditetapkan sebagai hari lahir Kota Serang (Tim Penyusun, 2011: 20).
} 
yang sampai sekarang masih ada dan menyisakan bangunan lama zaman kolonial adalah Kampung Kaujon,

Kampung Kubang, dan Kampung Kaloran. Bangunan rumah tinggal sebagai bangunan utama pemukiman dan bangunan pendukung keberadaan pemukiman, yang masih dapat diidentifikasi adalah Mesjid Kuno Kaujon, Rumah Tinggal Kuno Kaujon, Jembatan Kuno Kaujon, Makam $\mathrm{Ki}$ Uju, dan bekas lokasi Jembatan Kuno Kubang.

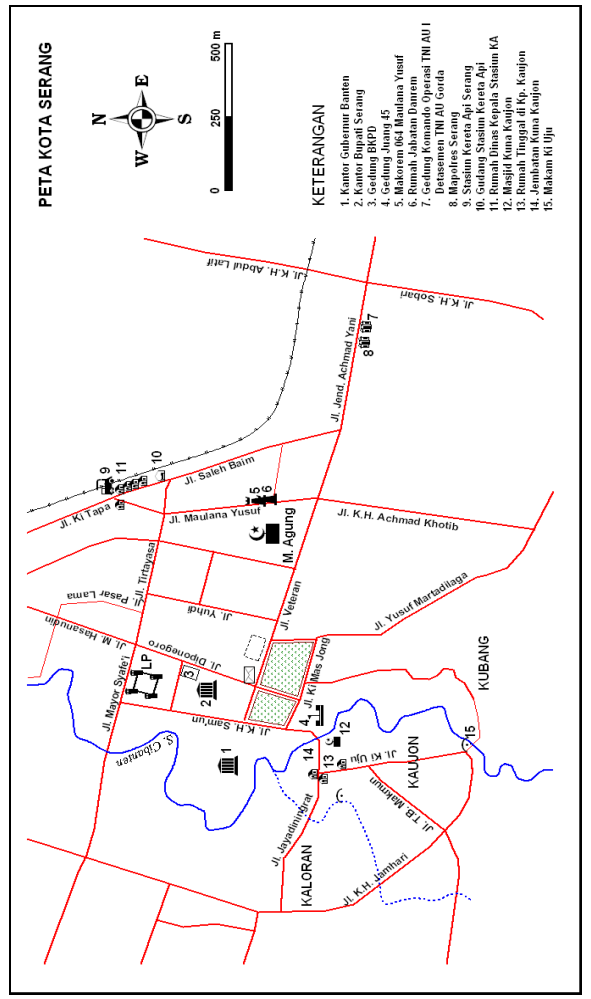

Jejak-jejak perkotaan kolonial pada

\section{Mesjid Kuno Kaujon}

Mesjid Kuno Kaujon terletak di Jl. RM. HS. Jayadiningrat, Kampung Kaujon Pasar Sore, Kelurahan Serang, Kecamatan Serang, pada $06^{\circ} 07^{\prime} 12,2^{\prime \prime}$ LS dan $106^{\circ} 08^{\prime} 09,83$ " BT. Bangunan berdiri di atas pondasi masif dengan tinggi $60 \mathrm{~cm}$, ruang utama empat persegi berukuran $10 \mathrm{x}$ $10 \mathrm{~m}$ dengan luas keseluruhan 703 meter $^{2}$. Dinding dilapisi tegel berwarna putih, dibatasi dinding pada keempat sisinya. Mihrab di dinding sebelah barat berupa ceruk tempat imam memimpin shalat. Memiliki atap tingkat bersusun tiga dengan mustoko di bagian atasnya. Di sebelah selatan terdapat tempat sholat perempuan/pawastren. Ragam hias arsitektural pengaruh lokal terlihat pada komponen pelipit dan mustoko. Pelipit biasa dijumpai pada bangunan candi dan mustoko banyak dijumpai pada bangunan tradisional Jawa. Dahulu memiliki pancaniti sebagai tempat azdan dan, pengumuman lain-lain. Karena faktor usia, pancaniti itu roboh dengan sendirinya. Sejak 1936 hingga 2002 telah mengalami renovasi, seperti penambahan pagar, jendela dan gudang, perbaikan ruang sholat perempuan dan lain-lain. Akan tetapi, bagian masjid yang asli masih tetap terjaga ${ }^{4}$.

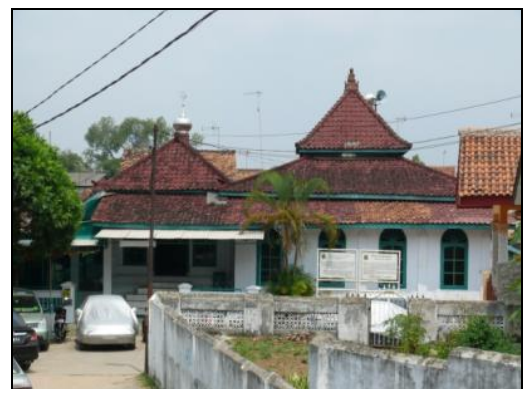

Selain sebagai tempat shalat, mesjid ini masih digunakan berbagai kegiatan keagamaan, seperti Majelis Ta'lim dan Tablig Akbar. Menurut Ustad Mukmin, tidak ada yang tahu tentang tahun pendirian mesjid, bahkan tiga generasi kakeknya pun tidak mengetahuinya. Akan tetapi, hampir semua orang tua yang sudah tinggal menetap lama di Kampung Kaujon mengatakan bahwa masjid kuno ini jauh

\footnotetext{
${ }^{4}$ Wawancara dengan Ustad Mukmin Satari, Ketua DKM (Kampung Kaujon, Serang, April 2011).
} 
lebih tua usianya dari usia jembatan kaujon yang dibangun tahun 1875 .

\section{Rumah Tinggal Kuno Kaujon}

Rumah tinggal kuno Kaujon terletak di Jl. RM. HS. Jayadiningrat, Kampung Kaujon, Kelurahan Serang, Kecamatan Serang, berada pada $06^{\circ} 07^{\prime} 12,2^{\prime \prime}$ LS dan $106^{\circ} 08^{\prime} 09,83^{\prime \prime}$ BT. Memiliki denah dasar persegi dengan atap genteng berbentuk atap limasan. Tidak memiliki halaman depan dan tidak berpagar, tetapi memiliki serambi depan dengan pagar tembok berlubang dengan tinggi \pm 1 meter. Pintu bagian muka berdaun tunggal dari kayu dan pintu rangkap berdaun ganda dari kaca berpanil dan kayu bertipe jalousi. Jendela depan dari kaca berpanil dan jendela rangkap berdaun ganda dari kaca berpanil di bagian dalamnya dan kayu bertipe jalousi di bagian luarnya. Kemudian memiliki tiang kayu persegi penyangga kanopi genteng di bagian muka. Lantai teras depan hampir sejajar dengan permukaan tanah, tetapi lantai bagian dalam ditinggikan sekitar $20 \mathrm{~cm}$ dari teras. Bahan lantai sudah baru dari keramik putih berukuran $30 \times 30 \mathrm{~cm}$. Pada sudut-sudut dinding muka terdapat tiang bergaya tuscan penguat bangunan yang menempel di dinding (pilaster).

Arsitektur bangunan bergaya Indis. Unsur Eropa terlihat dari jendela, pintu, dan tiang bargaya tuscan yang menempel di dinding. Juga jendela dan pintu berukuran besar dan tinggi. Sementara itu, unsur lokal tampak dari tiang kayu penyangga kanopi genteng di bagian depan, atap berbentuk atap limasan, dan adanya serambi muka/teras.

Menurut keterangan pemiliknya sekarang, rumah ini dahulunya adalah rumah berukuran besar dengan halaman luas di sekeliling bangunan. Halaman depan sampai ke jalan raya sekarang, memiliki bangunan penjaga dan berpagar. Bagian samping dan belakang juga berhalaman cukup luas dengan pagar di sekelilingnya. Akan tetapi, sekarang ini halaman sudah tidak ada, sudah berdiri rumah-rumah tinggal lain yang bukan satu kesatuan lagi dan berbeda kepemilikan. Dahulunya rumah tinggal pejabat Pangreh Praja pribumi. Kemudian mengalami pergantian kepemilikan ketika masuk zaman kemerdekan dan yang menempati rumah sekarang adalah pemilik ketiga. ${ }^{5}$

\section{Jembatan Kuno Kaujon}

Memasuki Kampung Kaujon dari arah pusat Kota Serang akan melewati jembatan kuno peninggalan Belanda yang dikenal sebagai Jembatan Kuno Kaujon, yang berdiri di atas Sungai Cibanten pada koordinat $06^{\circ} 07^{\prime} 05,51^{\prime \prime}$ LS dan 106 $09^{\prime} 03,59^{\prime \prime}$ BT. Jembatan ini dibangun tahun 1875. Pada kedua ujung jembatan terdapat dinding setinggi antara 1,5-2 m. Angka tahun pembangunan terpahat pada dinding di ujung jembatan sebelah barat sisi selatan. Pagar jembatan terbuat dari besi disusun bersilangan. Pada saat sekarang jembatan ini sudah tidak difungsikan untuk prasarana lalu lintas

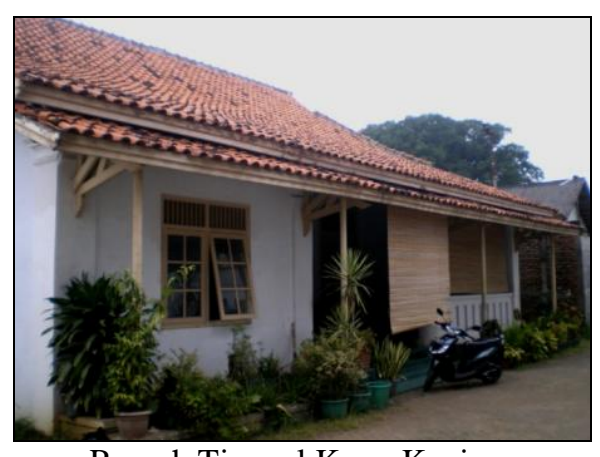

Rumah Tinggal Kuno Kaujon

kendaraan berat, hanya sepeda motor atau sepeda dan pejalan kaki.

\footnotetext{
${ }^{5}$ Wawancara dengan $\mathrm{Hj}$. Juariyah/H. Mukhlis, pemilik rumah (Kp. Kaujon, Serang, April 2011).
} 


\section{Makam Ki Uju}

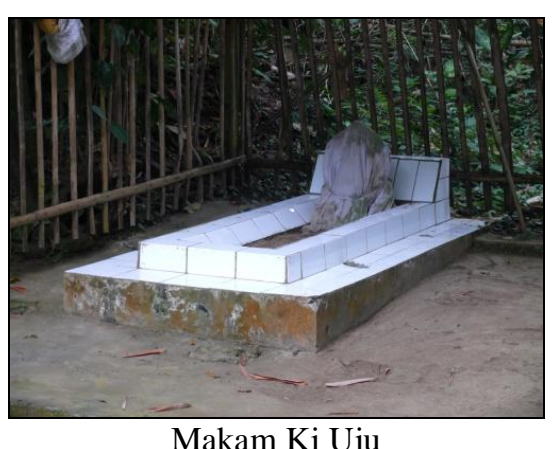

Di ujung selatan Kampung Kaujon di tepi Sungai Cibanten terdapat kompleks pemakaman. Salah satu tokoh penting yang dimakamkan adalah Ki Uju. Nama Kampung Kaujon ini berasal dari nama Ki Uju. ${ }^{6}$ Nama Ki Uju sekarang menjadi nama jalan di pertigaan jalan raya ke arah Pasar Sore Kaujon. Makam Ki Uju berada pada $06^{\circ} 07^{\prime} 20,96^{\prime \prime}$ LS dan $106^{\circ} 09^{\prime} 02,40^{\prime \prime}$ BT. Makam sudah dipugar. Sekeliling makam berpagar bambu dengan Jirat berundak berlapis keramik putih. Pada bagian utara (kepala) dinding jirat ditinggikan. Nisan tidak teridentifikasi karena terbungkus kain.

\section{Bekas Lokasi Jembatan Kuno Kampung Kubang}

Di sebelah utara kompleks makam $\mathrm{Ki}$ Uju terdapat jembatan baru menghubungkan Kampung Kaujon dengan Kampung Kubang. Dahulu jembatan

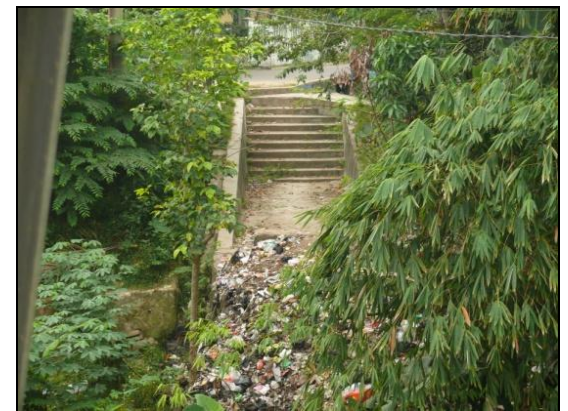

Bekas Jembatan Kuno Kp. Kubang

${ }^{6}$ Wawancara dengan H. Muslih, DKM Mesid Kubang dan Juru Kunci Pemakaman Umum Al-Barokah, Lingkungan Kubang Serang (Kp. Kubang, Serang, April 2011). tersebut merupakan jembatan gantung yang dikenal dengan sebutan Jembatan Gantung Kampung Kubang atau Jembatan Kubang. Jembatan ini terletak pada

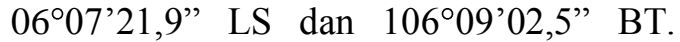
Sisa jembatan lama terlihat di bagian barat berupa landasan jembatan dari bahan dinding beton.

Pada dinding Sungai Cibanten di bawah Jembatan Kubang, terdapat jejak undakan memanjang dan beberapa lubang persegi. Menurut keterangan masyarakat setempat lubang tersebut adalah kubangan yang kemudian menjadi asal usul nama Kampung Kubang. Juga ada lubang bawah tanah atau gua. Menurut penuturan juru kunci Pemakaman Umum Kampung Kubang "Al-Barokah", lubang bawah tanah tersebut menembus sampai ke Banten Lama, sebagai jalan alternatif keluarga Sultan untuk mengamankan diri dari ancaman. Akan tetapi, sampai sekarang cerita ini tidak pernah dibuktikan dengan observasi langsung masuk ke dalam lubang bawah tanah untuk membuktikan adanya jalan pintas yang dapat dilalui orang. ${ }^{7}$

\section{a. Perkantoran}

Perkantoran atau kawasan pemerintahan berada di sebelah timur aliran Sungai Cibanten. Kawasan ini merupakan pusat kota yang terpusat di alun-alun (daerah Royal), yang terletak di depan kantor Gubernur pada ujung utara ruas Jl. Veteran. Akan tetapi, posisi alunalun tidak tepat berada di pusat kota, bergeser sedikit ke arah selatan. Komponen kota terpusat pada poros jalan raya dengan arah barat-timur, sekarang bernama Jl. Veteran yang berujung di depan kompleks kantor Gubernur (Karesidenan). Ke arah timur berlanjut dengan ruas Jl. A. Yani, ke arah barat dengan Jl. K.H. Sam'un, dan ke arah utara dengan Jl. Mayor Safe'i.

\footnotetext{
${ }^{7}$ Wawancara dengan H. Muslih, DKM Mesjid Kubang dan Juru Kunci Pemakaman Umum Al-Barokah, Lingkungan Kubang Serang (Kp. Kubang, Serang, April 2011).
} 
Bangunan perkantoran lainnya berada di sebelah utara alun-alun, di antaranya: Kantor Bupati, Kantor Pos, bekas lokasi markas Kodim 0506 Serang (sekarang sudah menjadi pusat perbelanjaan modern). Kemudian di sebelah utara kompleks Kantor Bupati, di sisi selatan ruas Jl. Mayor Safe'i terdapat bangunan lembaga pemasyarakatan. Selanjutnya adalah bangunan Mesjid Agung dan bangunan fasilitas perkantoran militer. Bangunan Mesjid Agung Serang tidak berada di sekitar alun-alun, tetapi berada di bagian timur kota. Kondisi mesjid yang tampak sekarang sudah mengalami renovasi total sehingga tidak menyisakan unsur bangunan lamanya. Di sebelah timur mesjid, pada ruas $\mathrm{Jl}$. Maulana Yusuf terdapat beberapa bangunan lama fasilitas perkantoran militer, yang juga dapat ditemukan di ujung timur kota, yaitu di ruas Jl. A. Yani.

\section{Kantor Gubernur Banten}

Bangunan Kantor Gubernur Banten berada di dalam Komplek Kantor Pemerintahan Provinsi Banten, di Jalan Brigjen KH. Syam'un No 5, Kelurahan Kota Baru, Kecamatan Serang, berada pada $06^{\circ} 06^{\prime} 56,73$ " LS dan $106^{\circ} 09^{\prime} 00,37^{\prime}$ " BT. Bangunan berada di lingkunan perkotaan dengan morfologi tanah berada di dataran rendah. Sebelah selatan berbatasan dengan Sekolah Mardi Yuana, sebelah timur dengan Jalan K.H. Syam'un, dan sebelah barat dengan Sungai Cibanten. Bangunan ini didirikan sekitar tahun 1814. Pada awalnya dipakai sebagai kantor Residen Banten dari tahun 1928. Setelah merdeka menjadi Kantor Karesidenan/Pembantu Gubernur Jawa Barat wilayah I Banten. Sampai sekarang berfungsi sebagai Kantor Gubernur Banten.

Kondisi bangunan sangat baik dan terawat. Berbentuk empat persegi panjang, menghadap ke timur dengan serambi muka ditopang oleh 8 pilar bergaya Tuscan putih. Pada bagian kiri dan kanan serambi terdapat jendela berdaun ganda dari kayu nerjenis jalosie. Tembok, bingkai pintu dan jendelanya berwarna putih. Atap bangunan berbentuk limasan dengan konstruksi kayu. Gentengnya tembikar coklat, sudah diganti genteng berglasur. Berdiri di atas pondasi masif ditinggikan sekitar $60 \mathrm{~cm}$ dari permukaan tanah, lantai bangunan telah berlapis marmer.

Pintu masuk bagian depan berjumlah 3 pintu merupakan pintu rangkap. Daun pintu rangkap pertama dari kayu dengan hiasan kayu jalosie dan seperempat bagian berbentuk panel biasa. Daun pintu rangkap kedua terbagi ke dalam 5 bagian, 4 panel teratas diberi kaca, satu panel yang terletak di bawah berbentuk panel biasa. Pada dinding sisi utara dan selatan terdapat 4 pintu berukuran sekitar 3,5 meter dan 5 jendela berukuran besar dengan tinggi 2,5 meter, dengan daun jendela bertipe jalosie. Pada bagian belakang terdapat 3 pintu dan 2 jendela jenis jalosie dengan bentuk dan ukuran yang serupa. Ruangan dalam dibagi

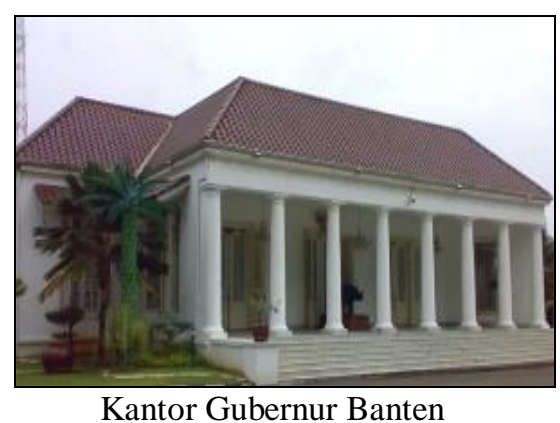

ke dalam 2 ruangan utama. Ruangan depan kini dipakai ruang tamu, memiliki dua pilar penopang bergaya tuscan. Ruangan kedua mempunyai ukuran lebih luas dari ruangan pertama, sekarang sebagai ruang rapat atau ruang serba guna. Memiliki 18 pilar tuscan, menopang atap ruangan dan 20 pilaster.

\section{Kantor Bupati}

Bangunan Kantor Bupati Serang terletak di dalam Komplek Kantor Pemerintahan Kabupaten Serang, di Jalan Veteran No. 1, Kelurahan Kota Baru, 
Kecamatan Serang. Berada pada $06^{\circ} 06^{\prime} 88,5^{\prime \prime}$ LS dan $106^{\circ} 09^{\prime} 12,7^{\prime \prime}$ BT, di lingkungan perkotaan dengan morfologi tanah dataran rendah. Sebelah utara berbatasan dengan Bappeda Kabupaten Serang/Jalan Kho Ternaya, sselatan dengan Jalan Veteran/Alun-alun, timur dengan DPRD Serang/Jalan Diponegoro, dan barat dengan Jalan K.H.

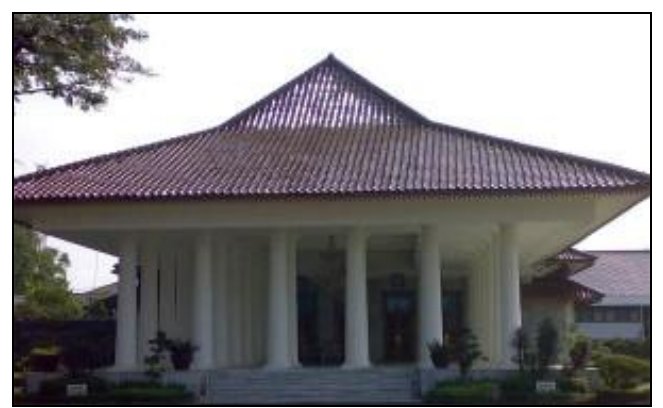

Kantor Bupati Serang

Syam'un/Kantor Gubernur Banten.

Dibangun seiring dengan pemindahan kota dari Banten Lama ke Serang pada paruh pertama tahun 1800-an. Sejak awal dibangun sampai sekarang sudah dijadikan sebagai kantor Bupati Serang. Tahun 2003 bangunan direnovasi oleh Pemerintahan Kabupaten Serang, dengan mengganti atap dan melapisi sebagian dinding bangunan dengan marmer. Secara keseluruhan kondisi fisik bangunan sangat baik dan tampak terawat. Pada bagian depan terdapat pendopo ditopang pilar-pilar bulat. Denah dasar empat persegi panjang dengan pondasi masif. Arah hadap ke selatan (Jalan Veteran) dengan serambi muka ditopang 32 pilar bergaya tuscan putih. Atap berbentuk limasan dengan konstruksi kayu. Genteng tembikar coklat, kini sudah diganti genteng berglasir. Bentuk atapnya lebih lebar berfungsi mencegah air hujan tampias ke dinding. Bentuk atap seperti ini dipengaruhi oleh arsitektur venakular Jawa. Bentuk-bentuk daun jendela dan daun pintu sudah banyak berubah, sekarang daun jendela dan daun pintu memakai ukiran kayu.

\section{Gedung BPKD}

Gedung Badan Pengelola Keuangan Daerah (BPKD) Kabupaten Serang terletak di sebelah timur Kantor Bupati Serang, di dalam Komplek Kantor Pemerintahan di Jalan Diponegoro No. 15, Kalurahan Kota Baru, Kecamatan Serang, pada 0606'9,46" LS dan 10609'18,3" BT. Sebelah utara dan barat berbatasan dengan perkantoran, sebelah timur dengan Jalan Diponegoro, dan sebelah selatan dengan pemukiman penduduk. Bangunan ini pernah dipakai sebagai "sekolah putri" pada masa kolonial, kemudian digunakan sebagai Sekolah Menengah Pertama Serang.

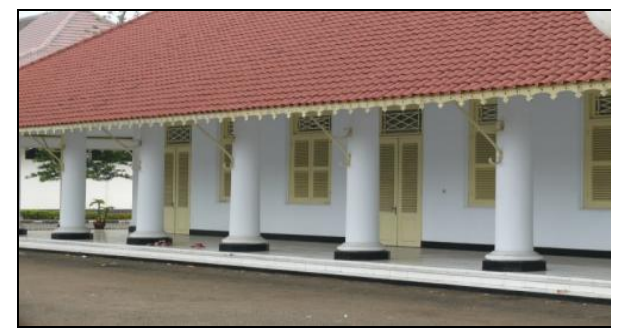

Bangunan terdiri dari dua bagian bangunan kembar, yaitu bangunan berlantai dua dan bangunan satu lantai. Bangunan berlantai satu di sebelah utara berbentuk bujur sangkar. Pada bagian depan terdapat koridor memanjang itopang oleh pilar-pilar bulat bergaya OrderTuscan. Terdapat serambi di sisi utara, timur dan selatan. Atap bangunan berbentuk limasan dengan konstruksi kayu dan lipsplang di bagian pinggir atap. Serambi sisi utara ditopang tiang berukuran besar berjumlah 14 tiang bergaya tuscan berwarna putih. Pada serambi utara terdapat 4 pintu dan 8 jendela berdaun ganda, berbentuk jalosie. Memiliki daun jendela rangkap, di bagian dalamnya terdapat daun jendela lagi tersusun dari panel-panel kaca. Bangunan berlantai dua, jendelanya bersusun simetris dengan kisi-kisi pada bagian atasnya. Memiliki atap limasan dengan konstruksi kayu. Bentuk pintu dan jendela sama 
dengan bangunan pertama, juga bentuk tiang bergaya tuscan dengan motif ukiran yang indah. Dengan demikian, bangunan ini berarsitektur Indis.

\section{Gedung Juang 45}

Gedung Juang 45 terletak di Jalan Ki Mas Jong No. 15, Kelurahan Kota Baru, Kecamatan Serang, berada pada $06^{\circ} 07^{\prime} 06,4^{\prime \prime}$ LS dan $106^{\circ} 09^{\prime} 07,7^{\prime \prime}$ BT. Memiliki luas 434,562 $\mathrm{m}^{2}$, dibangun di atas lahan seluas $3.970 \mathrm{~m}^{2}$, menghadap ke utara (Jalan Ki Mas Jong), terletak di pertigaan hook jalan, persimpangan $\mathrm{Jl}$. Ki Mas Jong dan jalan raya menuju Kampung Kaujon. Sebelah utara berbatasan dengan Alun-alun/Jalan Ki Mas Jong, selatan dengan daerah aliran Sungai Cibanten, timur dengan Gedung Dokkes Polda Banten, dan barat dengan TK Pertiwi/Jalan K.H. Syam'un. Keletakannya cukup strategis, di wilayah pusat pemerintahan Kota Serang, tidak jauh dari kawasan perdagangan Royal dengan morfologi dataran rendah. Pada masa Pendudukan Jepang pernah dijadikan markas Kempetai. Kemudian diambil alih oleh Tentara Keamanan Rakyat (TKR), yang dibentuk oleh KH. Syam'un, setelah berhasil merebut dan mengusir tentara Jepang melalui pertempuran 10 Oktober 1945.

Gedung Juang`45 dahulunya terdiri dari tiga bangunan. Satu bangunan masih asli yang kini menjadi Gedung Juang'45, dua bangunan lagi sudah tidak asli lagi dan sekarang digunakan sebagai kantor Polwil Banten dan kantor Dinas Kesehatan Kabupaten Serang/kantor Dokabu. Bangunan utama terbagi menjadi dua bagian simetris, bagian timur dan bagian barat. Pintu masuk utama ada dua sejajar menghadap utara dan bagian belakang gedung atau arah hadap ke selatan berpola sama dengan bagian depan, memiliki dua pintu sejajar menghadap arah yang sama. Memiliki tinggi sekitar 11 meter dengan teras di setiap sisinya. Sekarang ini teras yang masih ada hanya di bagian depan saja, sedangkan teras-teras di sisi-sisi lain sudah dialihfungsikan menjadi ruangan tertutup.

Gedung Juang'45 berarsitektur Indis, campuran antara unsur Neoklasik (Neoklasik Yunani dan Romawi), Modern

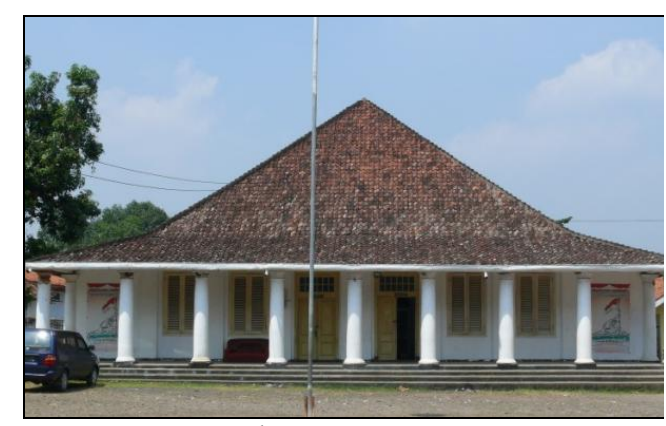

Gedung Juang '45

Arts, dan Local Style. Hal ini terlihat dari komponen pendukung, seperti pilar/kolom yang digunakan di setiap sisi bangunan, lantai, pintu, ukuran jendela, model ventilasi, dan struktur rangka atap joglo, dengan bentuk atap kerucut, sebagai pelindung utamanya. Memiliki kolomkolom berpenampang bulat tipe Order Doric/Tuscan (Neoklasik Yunani), terlihat dari bentuk kolom sangat sederhana, tidak banyak ornamen pada dekorasi di bagian kepala kolom. Unsur Modern Arts terlihat dari penggunaan material, terutama ventilasi kaca dan ventilasi besi yang dicetak menyerupai anyaman bambu. Sementara itu, gaya lokal tampak pada dominasi bentuk jendela krapyak dan atau joglo bertingkat dua. Selanjutnya gaya Neoklasik Romawi tampak pada penggunaan bentuk lengkungan setengah lingkaran di ambang pintu dan di lorong ruangan bagian dalam. Juga memiliki pilaster sebagai penguat konstruksi menyatu dengan dinding. Pilaster terbentuk dari pembangunan dinding sekat untuk memisahkan ruangan (Tim BP3 Serang, 2004).

Bangunan bergaya Tuscan ini memiliki halaman depan cukup luas dengan pagar tembok dan besi di sekelilingnya, berdenah dasar empat persegi panjang dan memiliki serambi muka menjorok ke depan. Bangunan 
tampak megah dengan 9 pilar penopang atap dan bangunan bercat putih. Pada bagian muka terdapat dua pintu masuk dan empat jendela, berdaun ganda berbentuk jalousi. Bagian kaki berbentuk pondasi masif ditinggikan sekitar $50 \mathrm{~cm}$ dari permukaan tanah, dengan beberapa anak tangga di bagian depan serambi. Bagian dalam terdapat lorong, di sebelah kiri dan kanan lorong terdapat ruangan-ruangan bevolume cukup besar. Atap bangunan berbentuk joglo dan memiliki sudut lancip di tengahnya, dengan konstruksi kayu dan gentengnya dari tembikar coklat.

\section{Gedung Korem 064 Maulana Yusuf}

Gedung Makorem 064 Maulana Yusuf terletak di Jl. Maulana Yusuf No. 10-15, Kelurahan Cimuncang, Kecamatan Serang, berada pada $06^{\circ} 06^{\prime} 96,2^{\prime \prime}$ LS dan $106^{\circ} 09^{\prime} 49,5^{\prime \prime} \mathrm{BT}$, dengan ketinggian $31 \mathrm{~m}$ dpl. Sebelah utara berbatasan dengan Hotel Wisata, sebelah selatan dengan Denpom Serang dan gereja, sebelah timur dengan areal perumahan penduduk dan Jalan M. Saleh Baimin, dan sebelah barat dengan Jalan Maulana Yusuf. Bangunan ini dahulunya pernah digunakan sebagai gedung sekolah Noormal School. Kemudian pernah difungsikan sebagai tangsi Marsose (tentara elit Belanda). Gedung utama difungsikan sebagai Kantor Tentara Belanda, sedangkan bangunan lainnya diperkirakan digunakan sebagai bangunan asrama dan ruangan tahanan. Perkiraaan ini berdasarkan ciri-ciri yang sama dari bentuk denah, luas ruangan, pintu, ventilasi, serta teras atau koridor.

Gedung Makorem sudah berdiri sejak masa Pemerintahan Hindia Belanda, berdasarkan angka tahun yang tertulis di bagian atas teras muka, "ANNO 1910". Akan tetapi, belum ada informasi tahun pendiriannya secara pasti. Pada tahun 1950 secara resmi gedung ini diserahkan dari Pemerintah Belanda (tentara KNIL) ke Pemerintah Indonesia dan difungsikan sebagai markas Tentara Nasional Indonesia. Dari tahun 1964 sampai sekarang berfungsi sebagai Makorem 064 Maulana Yusuf (Tim BP3 Serang, 2006).

Bangunan utama sebagai bangunan lama terletak di bagian depan menghadap ke barat. Berdenah empat persegi panjang, terdiri dari dua bagian bangunan menyilang, sehingga terdapat pola simetris antara sisi utara dan selatan bangunan. Pada bagian tengah di antara kedua bagian tersebut terdapat pintu masuk menjorok ke muka dan memanjang ke belakang. Memiliki bentuk atap limasan bersusun dua dari genteng. Pada bagian sudut atap utara dan selatan terdapat hiasan sudut berbentuk bola. Antara atap bangunan dan atap serambi memiliki lubang ventilasi

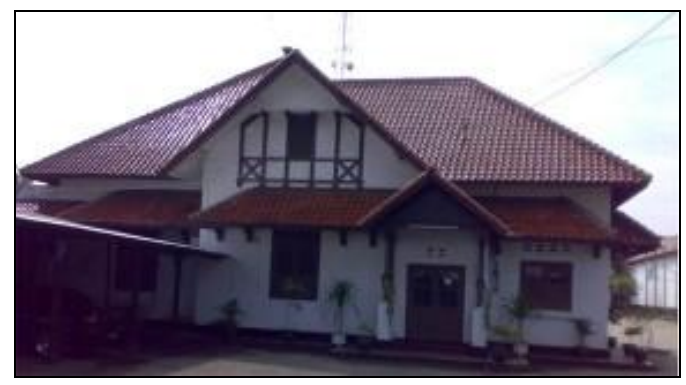

Gedung Korem 064 Maulana Yusuf

berbentuk sejajar. Pada bagian muka terdapat kanopi memayungi tiga gerbang pintu utama berbentuk lengkungan dengan hiasan bersusun dan ukiran kayu berbentuk kipas. Bangunan ini memiliki 18 tiang ganda dari kayu dengan umpak tembok setinggi $50 \mathrm{~cm}$ menopang atap serambi muka. Kemudian terdapat empat tiang lagi pada sisi kiri dan kanan bangunan. Pondasi bangunan masif dengan ketinggian sekitar $20 \mathrm{~cm}$ dari permukaan tanah (Tim BP3 Serang, 2006).

\section{b. Perdagangan}

\section{1) Pasar Lama}

Pasar Lama merupakan salah satu pasar yang menjadi tujuan masyarakat Serang dalam berbelanja kebutuhan pokoknya. Pasar Lama terletak masih dalam kawasan Royal, yaitu dari simpang Pocis menuju Kebaharan. Pasar Lama adalah pasar yang sudah lama beroperasi, 
terdapat beberapa pertokoan yang berjejer yang bersambung sampai ke Royal, dari mulai toko sepeda, toko obat, toko tekstile, bank-bank dan para pedagang kaki lima yang berjejer sepanjang jalan. Untuk berbelanja kebutuhan pokok sekarang ini hanya terdapat pasar kaget yang beroperasi pada tengah malam hingga menjelang jam 9 pagi. Para penjual kebutuhan pokok hanya menggelar dagangannya di pinggir jalan. Penjual sayur, ikan, bumbu dapur, rempah-rempah, buah-buahan, dan lainlain dapat ditemukan sepanjang jalan.

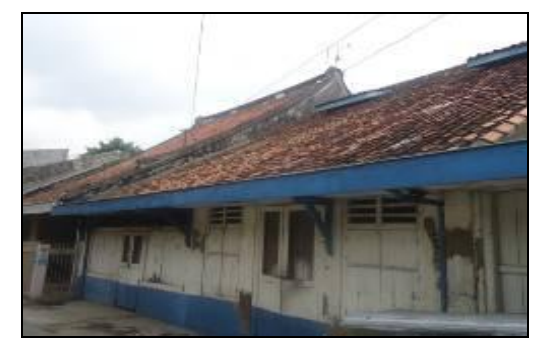

Rumah Tinggal Kolonial di Pasar Lama

Lokasi Pasar lama merupakan blok pertokoan/kios-kios yang terletak satu blok dari keletakan lokasi keberadaan gedung Lembaga Pemasyarakan, tepatnya berada di ruas Jl. Maulana Hasanuddin dan Jl. Tirtayasa. Di blok Pasar Lama ini masih dapat dilihat beberapa bangunan kolonial khas pertokoan zaman kolonial atau rukuruko milik para pedagang Cina peranakan. Tampak beberapa rumah/ruko berarsitektur Tiong Hoa dan masih bertahan sampai sekarang.

\section{2) Gedung Stasiun Kereta Api Serang}

Di ujung ruas Jl. Tirtayasa di sebelah timur bersatu dengan ruas Jl. Saleh Baim yang melintang arah utara selatan terdapat bangunan Stasiun Kereta Api Serang. Jalur rel kereta api ini sejajar dengan ruas J1. Saleh Baim, sedangkan di bagian selatan kemudian berbelok ke timur sejajar dengan ruas Jl. Ahmad Yani.

Bangunan Stasiun Kereta Api Serang terletak di Jalan Ki Tapa No. 2, Kelurahan Cimuncang, Kecamatan Serang, pada $06^{\circ} 06^{\prime} 44,5^{\prime \prime} \mathrm{LS}$ dan $106^{\circ} 09^{\prime} 31,2^{\prime \prime} \mathrm{BT}$ dengan ketinggian $\pm 25,66 \mathrm{~m}$ dpl. Memiliki batas-batas di sebelah utara dengan Jalan Raya Semaun Bakri, selatan dan timur dengan pemukiman penduduk, dan barat dengan Jalan Ki Tapa. Lingkungan Stasiun Kereta Api Serang berada di kawasan perdagangan dan jasa dengan orientasi arah barat. Bangunan stasiun menghadap ke arah barat. Pondasi bangunan ditinggikan sekitar $60 \mathrm{~cm}$ dari permukaan tanah.

Bangunan ini memanjang seperti kebanyakan stasiun kereta api. Di depan pintu masuk terdapat kanopi yang menjorok keluar. Memiliki 3 jalur KA dan 2 peron, terletak di Daerah Operasi I Jakarta dan merupakan stasiun kereta api terbesar di Kota Serang. Stasiun ini mulai dibuka 20 Desember 1900. Sampai sekarang arsitekturnya masih asli, selain telah dilakukan beberapa perbaikan berupa pengecatan ulang dan penggantian lantai.

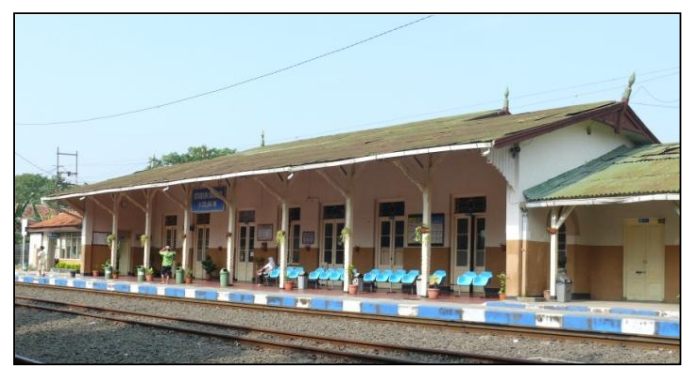

Stasiun Kereta Api

Bangunan stasiun ini terdiri dari 5 bagian, memanjang berderet dari utara ke selatan, dengan tiga bangunan penunjang. Pertama, berupa bangunan permanen sebagai ruang kantin. Kedua, terdiri dari dua ruang sebagai mushola dan pos polisi. Ketiga, bangunan utama terdiri dari tiga ruang sebagai ruang rapat, ruang tunggu, dan ruang loket. Keempat, berdenah sejajar bangunan pertama dan kedua adalah ruang kepala. Kemudian bagian kelima terletak paling selatan merupakan bangunan baru sebagai ruang operator atau PPKA. Pada bangunan inti (dari bagian bangunan kedua sampai kelima) terdapat teras sepanjang 
bangunan, berupa ruang terbuka dengan atap yang disangga dengan tiang-tiang kayu berprofil sebanyak delapan tiang. Memiliki lantai keramik merah dengan dinding pasangan bata diplester pada sisi utara dan selatan. Pada bagian dinding utara terdapat ambang pintu berbentuk lengkung (Achmadi et al, 2005).

Komponen bangunan stasiun seperti daun pintu dan jendela bertipe jalousie atau dibuat dari kayu bersusun horisontal. Denah berbentuk bujur sangkar dengan pondasi yang ditinggikan. Atap bangunan ditutup oleh seng, di sudut atap terdapat hiasan berbentuk pucuk bunga. Bagian dinding kebanyakan dilengkapi dengan ragam hias plipit, terutama di bagian atas jendela, di bawah lisplang dan atap dinding dengan bagian bawah (Achmadi et al, 2005).

\section{c. Nilai-Nilai Sejarah dan Budaya dalam Pembagian Wilayah Perkotaan di Kota Serang}

Pembagian wilayah perkotaan dan perubahan arsitektur bangunan di Kota Serang merupakan perihal yang disengaja dan direncanakan oleh Pemerintah Kolonial Belanda. Sejarah telah mencatat bahwa segala seuatu yang dilakukan pemerintah kolonial Belanda, semata-mata untuk kepentingan mereka sendiri sebagai penguasa. Menurut Martin Heidegger bahwa manusia ditandai ciri historisitas (historicity), yang terus berusaha melakukan perubahan-perubahan dalam bentuk ide-ide kreatif dan hasil karya yang bermutu tinggi. Ciri historisitas tampak jelas pada diri setiap manusia, baik sebagai individu maupun sebagai komunitas dengan budayanya sendiri. Kontinuitas perkembangan suatu peradaban akan tetap lestari dalam suatu rekaman sejarah. Dalam rekaman tersebut yang mengandung nilai-nilai luhur akan dipelihara sebaikbaiknya untuk terjaganya identitas diri dan komunitasnya.

Pembagian wilayah di Kota Serang yang terbagi menjadi 3 bagian wilayah tidak terlepas dari ciri historisitas dari manusia, baik sebagai individu maupun sebagai warga dari komunitas. Pembagian tersebut merupakan kreativitas pendirinya untuk lebih menyesuaikan diri dengan lingkungan dan kebutuhan hidup ketika itu. Pada zaman kolonial, tata letak kota yang baik menjadi hal mutlak untuk keberlangsungan dan kemajuan kota itu sendiri dan masyarakat pendukungnya. Dengan melihat setting kota di masa sebelum kedatangan bangsa Eropa, Serang adalah kota yang berorientasi kepada tata letak kota bercirikan Jawa Kuno dan pengaruh budaya Islam, yang mana alunalun menjadi sentra, dikelilingi oleh adanya mesjid, penjara, bangunan pemerintahan, dan lain-lain.

Seperti yang diungkapkan G.J. Reiner (1997) bahwa tanpa pengalaman masa lalu tidak mungkin untuk membangun ide-ide tentang konsekuensi dari tindakan kita. Hal ini menunjukkan adanya hubungan masa lalu dengan masa kini untuk proyeksi di masa yang akan datang. Berdasarkan pengertian ini, pada zaman kolonial tata letak Kota Serang mengalami sedikit perubahan, tampak dari pembagian secara klaster-klaster, letak mesjid yang bergeser, dan fungsi alun-alun yang tidak lagi sebagai sentra kota. Hal ini dimungkinkan terjadi karena pada zaman kolonial fungsi alun-alun tidak lagi sama dengan fungsi sebelumnya. Pemerintah kolonial lebih menekankan komunikasi dengan rakyat jajahannya melalui perantara, yaitu pejabat pangreh praja pribumi dengan cara-cara yang tidak lagi konservatif. Dahulu rakyat dikumpulkan di alun-alun untuk menerima perintah raja atau pengumuman tentang suatu hal penting dari penguasa. Setelah Belanda berkuasa, cara-cara seperti itu sudah ditinggalkan dan telah digunakan cara-cara menurut kepentingan penguasa kolonial.

Dalam catatan sejarah bahwa pada tahun 1808, Pemerintah Hindia Belanda menghancurkan Keraton Surosowan dan pusat Kerajaan/Kesultanan Banten dipindahkan ke Keraton Kaibon. Kemudian 1816, kekuasaan kerajaan 
dihapuskan dan dijadikan Karesidenan Banten bertempat di Keraton Kaibon. Pada tahun 1828 pusat pemerintahan dipindahkan lagi ke Kota Serang. Pergeseran dan perpindahan kekuasaan (politik) dari Banten Lama ke Kota Serang mempengaruhi arah perkembangan kota, terutama Kota Serang yang kemudian menjadi pusat Pemerintahan Kolonial Belanda. Kemudian bangunan pusat pemerintahan dan pendidikan di Kota Serang merupakan satu kesatuan, saling melengkapi dalam operasional pemerintahan sehari-hari. Selain itu, Serang juga terkenal sebagai kota pelabuhan dan perdagangan regional dan internasional. Oleh karena itu, dibangunan beberapa fasilitas perkantoran, perdagangan, pergudangan, sarana publik, dan fasilitas bangunan lainnya, yang dibangun di pusat kota dan di pinggirpinggir kota sebagai hinterland Kota Serang (Tim Peneliti, 2011: 109).

Permukiman mempunyai lingkup tertentu, yaitu kawasan yang didominasi oleh lingkungan hunian dengan fungsi utama sebagai tempat tinggal dilengkapi dengan prasarana, sarana lingkungan, dan tempat kerja terbatas, sehingga berdaya guna dan berhasil guna, seperti: (1) jaringan jalan untuk mobilitas manusia dan angkutan barang, (2) jaringan saluran pembuangan air limbah dan tempat pembuangan sampah untuk kesehatan lingkungan, dan (3) jaringan saluran air hujan untuk drainase dan pencegahan banjir setempat. $^{8}$ Dalam hal ini Kota Serang memiliki ketiga unsur penting sebagai kawasan permukiman. Adanya jalan-jalan lurus dan berpotongan sebagai pembentuk dan pembatas blok-blok pemukiman dan perkantoran, serta pusat pertokoan dan pasar di pusat Kota Serang. Kemudian beberapa blok permukiman tersebut dapat ditempuh dengan berjalan kaki dan menaiki kendaran bermotor, baik roda dua maupun roda empat atau lebih. Di

\footnotetext{
${ }^{8}$ Undang-undang Republik Indonesia Nomor 4 tahun 1992 tentang Perumahan dan Permukiman, Bab I, Pasal 1.
}

antara ruas-ruas jalan raya dan jalan perkampungan terdapat saluran air dan lokasi pembuangan sampah. Seperti yang tampak di sekitar daerah hunian/klaster perkampungan. Demikian juga di klaster perkantoran dan perdagangan. Saluran air tersebut juga berfungsi sebagai penampung dan pembaungan air hujan, sehingga genangan air dapat dicegah seminim mungkin.

Salah satu unsur dari permukiman adalah pemukiman. Mundardjito mengemukakan bahwa pemukiman adalah tempat orang bermukim secara fisik dapat dilihat dengan nyata (1990: 20). Pemukiman terencana biasanya berkaitan dengan keberadaan kota. Pengertian kota menurut Max Weber (1966) mempunyai ciri-ciri, yaitu (1) adanya pasar, (2) memiliki sistem hukum sendiri, dan (3) bersifat kosmopolitan (1966: 4). Kota juga merupakan suatu tempat dengan penghuninya yang dapat memenuhi sebagian besar kebutuhan ekonominya di pasar lokal. Barang-barang yang ada dihasilkan penduduk setempat di pedalaman dan diperjualbelikan di pasar lokal di daerahnya (Nuralia, 2011:101).

Pemukiman di Kota Serang pada zaman Belanda adalah tempat bermukim yang terdiri dari orang-orang Belanda sebagai golongan penguasa, orang-orang Timur Asing (Cina) sebagai perantara, dan golongan pribumi sebagai penduduk asli. Kedua golongan terakhir adalah orang yang berada di bawah kekuasaan golongan pertama dan hidupnya sangat tergantung kepada kebijakan penguasa. Kemudian sebagai kota terencana, Serang di masa kolonial Belanda memiliki ketiga unsur kota yang disebutkan Weber, yaitu adanya pasar (sekarang pasar lama), adanya sistem hukum (hukum kolonial ketika itu), dan memiliki ciri-ciri kosmopolitan dengan adanya pusat perkantoran, pemerintahan, pendidikan, jalan dan alat transportasi yang memadai, serta sarana pendukung kota lainnya.

Dengan terpenuhinya unsur-unsur pembentuk kota, penduduk Kota Serang 
zaman kolonial sangat heterogen dengan bercampurnya beragam etnis beserta budayanya. Dr. K. Kupper mengatakan bahwa kebudayaan merupakan sistem gagasan yang menjadi pedoman dan pengarah bagi manusia dalam bersikap dan berperilaku, baik secara individu maupun kelompok. Suatu kumpulan peralatan simbolik untuk mengatur perilaku, sumber informasi yang ekstrasomatik. Kebudayaan merupakan suatu sistem simbolik, maka proses budaya haruslah dibaca, diterjemahkan, dan diinterpretasikan (Kupper, 1999: 98). Kemudian menurut Clifford Geertz kebudayaan adalah seperangkat teks-teks simbolik yang perlu diinterpretasikan maknanya sebagai suatu pola perilaku yang sifatnya kongkrit, suatu pendeskripsian yang sifatnya mendalam (thick description) (Geertz , 1992: 5).

Berdasarkan dua pengertian kebudayaan tersebut, nilai-nilai budaya yang terkandung di dalam pembagian wilayah permukiman di Kota Serang dan perubahan arsitektur bangunan penunjangnya menjadi sangat jelas. wilayah perkampungan menjadi wilayah hunian yang terdiri dari beberapa unsur pembentuknya (manusia) dengan budaya yang berbeda. Di sana tinggal orang-orang Eropa (Belanda) dengan budaya Baratnya di lokasi yang lebih mendekati pusat kota, walaupun beberapa di antara mereka (pejabat tinggi pemerintahan) tinggal di wilayah perkantoran. Kemudian orangorang pribumi asli dengan budaya Indonseia (campuran antara Sunda, Jawa, dan Lampung) di kawasan pemukiman yang sama, tetapi sedikit bergeser dalam kelompok komunitasnya. Di antara orangorang pribumi ada sebagian yang tinggal di wilayah perkantoran dan perdagangan. Sementara itu, orang-orang Cina juga bermukim di lokasi yang sama dan bercampur tanpa penegasan batas wilayah yang jelas. Akan tetapi, sebagian orangorang Cina sebagaimana di kota-kota lain, terkonsentrasi dalam kawasan "Pecinan" di wilayah perdagangan/sentra perekonomian di Pasar Lama. Beberapa dari orang-orang
Cina tersebut bermukim di wilayah perdagangan (Pasar Lama) bergabung dengan toko atau kiosnya (rumah toko/ruko). Dengan bercampurnya beragam etnis dan budaya, khususnya di wilayah perkampungan, menjadi penentu keterbukaan di antara mereka, sikap saling menghargai dan toleransi yang besar, sehingga dapat hidup bersama dalam satu kawasan hunian.

Mengenai tempat hunian penduduk Kota Serang, baik yang berada di wilayah pemukiman, perkantoran, maupun perdagangan, bentuk dan gaya arsitektur bangunannya merupakan campuran dari arsitektur lokal dan pengaruh unsur-unsur Eropa dan Cina. Demikian juga dengan bangunan ruko dan kantor mengandung ketiga unsur budaya pembentuknya tersebut. Gaya campuran ini tampak dari bentuk atap joglo (Jawa), julang ngapak (Sunda) dan atap rumah kampung, serta bahan bangunan (tradisional Indonesia), tiang-tiang dan pilaster, pintu, jendela, dan dinding (Eropa), serta sebagian bentukan ujung atap yang meruncing (Cina) (Handinoto, 2010).

Selanjutnya seperti yang telah diungkapkan oleh sejarawan Kuntowijoyo bahwa manfaat sejarah dapat memberi pengetahuan langsung dengan adanya pengaruh Eropa terhadap bangunan rumah tinggal, terutama bentuk dan arsitektur bangunannya. Konstruksi dinding bangunan pada zaman kolonial telah menggunakan teknik baru, yaitu memakai bata merah dan semen yang merupakan pengaruh teknologi Eropa, terutama pada teknik pemasangan batanya. Semen digunakan sebagai perekat bata merah. Sebelum datangnya teknik pemasangan bata dan perekatnya, konstruksi dinding berupa konstruksi tumpuk dengan lumpur sebagai perekat. Penggunaan lumpur ini terbatas karena mengakibatkan pecahnya bata, kekeringan yang disebabkan sinar matahari langsung. Konstruksi bangunan tembok tebal sebagai penguat untuk 
mengantisipasi panas (Sumintarja, 1981: 11).

\section{PENUTUP}

Perkotaan kolonial pada zaman Pemerintahan Hindia Belanda (pada abad XIX - XX) di Kota Serang, ditandai dengan pembagian wilayah permukiman menjadi 3 wilayah, yaitu pemukiman, perkantoran, dan perdagangan. Ketiga wilayah permukiman ini ditandai dengan adanya konsentrasi bangunan yang sejenis di suatu bagian wilayah kota. Bangunan pemukiman/tempat tinggal dan bangunan pendukung pemukiman lainnya banyak ditemukan di wilayah Kampung Kuno Kaujon, yang terletak di sebelah barat aliran Sungai Cibanten. Bangunan perkantoran/pemerintahan terkonsentrasi di pusat Kota Serang (daerah Royal), yang terletak di sebelah timur aliran Sungai Cibanten. Kemudian bangunan perdagangan berada di wilayah Pasar Lama, masih dalam kawasan Royal, yaitu dari simpang Pocis menuju Kebaharan. Ketiga bagian wilayah ini masih tampak dalam peta wilayah Kota Serang pada masa sekarang.

Perubahan sosial politik yang terjadi di Kota Serang mengandung nilai-nilai sejarah dan budaya, yang tercermin dari perubahan tata letak kota dan gaya arsitektur bangunan fasilitas pendukung kota terencana pemerintah kolonial Belanda. perubahan juga tampak dari sikap yang lebih terbuka terhadap masuknya unsur-unsur budaya asing yang tercermin dari sikap hidup yang lebih toleran dan lahirnya gaya arsitektur campuran/Indis sebagai gaya yang trend saat itu.

\section{DAFTAR SUMBER}

\section{Buku}

Geertz, Clifford. 1992.

Tafsir Kebudayaan (terjemahan dari Interpretation of Culture). Yogyakarta: Kanisius Press
Handinoto. 2010.

Arsitektur dan Kota-kota di Jawa

Pada Masa Kolonial. Yogyakarta:

Graha Ilmu

Heidegger, Martin. 1974.

Identity and Difference, New York:

Harper

Kuntowijoyo. 1994.

Metodologi Sejarah. Yogyakarta: Jurusan Serajah, Fakultas Sastra, Universitas Gadjah Mada. 2001.

Pengantar Ilmu Sejarah.

Yogyakarta: Yayasan Bentang Budaya (terj.) Abdul Hakim dari Jaarboek van Batavia en Omstreken. Jakarta : PT Metro Pos

Kuper, Adam. 1999.

Culture. Cambridge: Harvard University Press

Lubis, Nina Herlina. 2004.

Banten Dalam Pergumulan Sejarah: Sultan, Ulama, Jawara. Jakarta: LP3ES.

Mundardjito, 1990.

Metode Penelitian Permukiman Arkeologis. Dalam Edi Sedyawati, ed. Monumen: Karya Persembahan Untuk Prof. Dr. Soekmono. Depok: Fakultas Sastra Universitas Indonesia.

Nuralia, Lia. 2011.

Pemukiman di Pusat Kota Subang: Bangunan Bersejarah Peninggalan Perusahaan Perkebunan Pamanoekan En Tjiasem Landen. Dalam Ali Akbar (Editor), Arkeologi Peran Dan Manfaat Bagi Kemanusiaan. Bandung: Al-Qaprint. Halaman 99-116

Reiner, G.J. 1997. 
History Its Purpose and Methods. George Allen and Unwim Ltd, London

Said dan Bambang Budi Utomo. 2006. Permukiman dalam Perspektif Arkeologi. dalam Truman Simanjuntak, Permukiman di Indonesia Perspektif Arkeologi. Jakarta: Departemen Kebudayaan dan Pariwisata, Badan Pengembangan Sumberdaya Kebudayaan dan Pariwisata.

Sumintarja, D. 1981.

Kompendium Sejarah Arsitektur, Jilid I. Bandung: Yayasan Lembaga Penyelidikan Masalah Bangunan.

Weber, Karl Emil Maximilian. 1996.

The City. Translated and Edited by Don Martindale and Gerturd Neuwirt. New York: The Free Press

Yunus, Hadi Sabari. 1987.

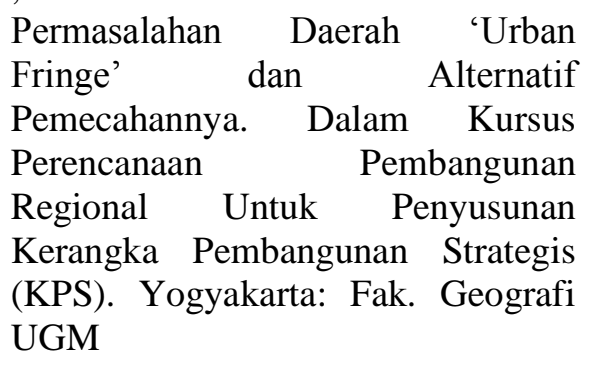

\section{Laporan Penelitian}

Achmadi, Syarif, et al. 2005.

Laporan Penilaian Bangunan Stasiun Kereta Api Serang dan Karangantu, Kabupaten Serang. Serang: BP3 Serang, wilayah Kerja Provinsi Banten, Jawa Barat, DKI Jakarta, dan Lampung.

Tim Penyusun. 2011.

Laporan Penelitian Arkeologi: Permukiman Puncak-Puncak Peradaban Awal Masehi Sampai Masa Kolonial di Kabupaten Serang dan Sekitarnya, Provinsi Banten.
Bandung: Balai Arkeologi Bandung (tidak diterbitkan)

Tim BP3 Serang. 2004.

Laporan Inventarisasi Bangunan Kolonial di Kabupaten Serang. Serang: BP3 Serang, wilayah kerja Provinsi Banten, Jawa Barat, DKI Jakarta, dan Lampung

Tim BP3 Serang. 2004.

Laporan Pemetaan, Penggambaran, dan Pembobotan Gedung Juang Serang. Serang: BP3 Serang, wilayah kerja Provinsi Banten, Jawa Barat, DKI Jakarta, dan Lampung.

Tim BP3 Serang. 2006.

Laporan Pemetaan, Penggambaran, dan Pembobotan Gedung Makorem 064 Maulana Yusuf Serang. Serang: BP3 Serang, wilayah kerja Provinsi Banten, Jawa Barat, DKI Jakarta, dan Lampung

\section{Internet}

"Pengertian pemukiman", dalam http://kuliaharsitektur.wordpress.co $\mathrm{m} / 2008 / 11 / 15$, diakses 12 Februari 2012

\section{Informan}

Satari, Mukmin. 2011.

Ketua DKM Mesjid Kuno Kaujon di Kampung Kuno Kaujon. Wawancara. Serang, April 2011.

Muslih. 2011.

Ketua DKM Mesjid Kubang dan Juru Kunci Pemakaman Umum AlBarokah di Kampung Kubang. Wawancara. Serang, April 2011.

Juariyah. 2011.

Pemilik Rumah Kuno di Kampung Kuno Kaujon. Wawancara. Serang, April 2011.

Mukhlis. 2011. 
Pemilik Rumah Kuno di Kampung

Kuno Kaujon. Wawancara. Serang,

April 2011. 